\title{
PENGUKURAN INFILTRASI DALAM KAWASAN TEKNOPARK PELALAWAN
}

\author{
Measurement of Infiltration in Pelalawan Technology Park
}

Oleh :

\section{R. Haryoto Indriatmoko, I Putu Angga Kristyawan dan Ahmad Shoiful}

Pusat Teknologi Lingkungan, BPPT

Jl. M.H. Thamrin No. 8 Gd. II Lt. 18 Jakarta 10340

\begin{abstract}
Abstrak
Kawasan Teknopark Pelalawan merupakan sebuah kawasan yang didisain sebagai pusat pengembangan dari keunggulan lokal yang dihasilkan melalui sebuah riset. Di dalam kawasan terdapat sekolah Tinggi Teknologi Pelalawan dan Pusat Penelitian dan Pengembangan untuk mengembangkan produk lokal, industri hilir sawit, produk-produk hutan dan industri skala kecil dan menengah. Fasilitas dan sarana pendukung seperti air bersih, air limbah dan sistem drainase saat ini sedang disiapkan kedalam sebuah dokumen master plant kawasan teknopark Pelalawan. Pengukuran infiltrasi kawasan merupakan bagian dari kegiatan pendukung untuk perencanaan sistem pengelolaan air hujan kawasan. Pengukuran infiltrasi kawasan dilakukan pada dua land unit are yaitu land unit kering dan land unit lahan basah bergambut. Pengukuran infiltrasi dilakukan dengan menggunakan double ring infiltrometer. Metoda analisa infiltrasi dilakukan dengan menggunakan persamaan Kostiokov. Hasilnya adalah : laju infiltrasi di lahan kering 1,5 $\mathrm{mm} /$ menit sedang pada lahan basah bergambut adalah $0,4 \mathrm{~mm} /$ menit. Kesimpulan yang dapat diambil dari penelitian ini adalah pengelolaan air hujan akan lebih efisien dilakukan pada land unit kering.
\end{abstract}

Kata Kunci : teknopark Pelalawan, laju infiltrasi, kostiakov, double ring infiltrometer, laju infiltrasi konstan

\section{Abstract}

Teknopark Pelalawan area is an area designed as a center for the development of local advantages generated through research. In the region there will be College of Technology Palalawan and various Research and Development Center as to the development of local products, industrial downstream palm oil products, forest products and small and medium scale industries. Means and supporting facilities such as clean water, waste water and drainage systems are currently being incorporated into the master document teknopark region Palalawan plants. Infiltration measurements conducted to support the planning of drainage systems in order to manage rainwater in the area of teknopark Palalawan. This measurement is done in both land area units, namely: dry land units and land units of wet peat. Infiltration measurements done using an instrument called a double ring infiltrometer. To measure the rate of infiltration were analyzed using Kostiokov method. The result is: infiltration in the drylands of $1.5 \mathrm{~mm} / \mathrm{min}$ on a peaty wetland was $0.4 \mathrm{~mm} /$ min. The conclusion that can be drawn is that in order to manage the rainwater would be more efficiently carried out on dry land unit.

Keywords: teknopark Pelalawan, infiltration rate, kostiakov, double ring infiltrometer, constant infiltration rate

\section{PENDAHULUAN}

Program pengembangan Sciencepark atau Teknopark bertujuan untuk mengembangkan sebuah wilayah melalui keunggulan lokal. Melalui program tersebut diharapkan dapat terjadi interaksi dan integrasi antara iptek dengan kalangan industri dan pemerintah, sehingga kualitas produksi yang dihasilkan melalui riset pada akhirnya dapat meningkatkan nilai tambah suatu produk sehingga perekonomian wilayah pada khususnya dan secara nasional meningkat.

Demikian pula yang terjadi di kawasan Teknopark Pelalawan, progres kegiatan fisik yang sedang disiapkan sampai dengan saat ini adalah menyiapkan dokumen untuk prasaran fisik seperti 
sarana dan prasarana air bersih, air limbah dan perencanaan sistem drainase dalam kawasan.

Dalam mendukung perencanaan sistem drainase kawasan, telah dilakukan lapangan untuk pengukuran laju infiltrasi di dalam lokasi kawasan. Perhitungan terhadap laju infiltrasi ini penting untuk mengetahui kecepatan air hujan meresap kedalam tanah. Air hujan yang jatuh diatas permukaan wilayah yang terbangun merupakan sumber air yang sangat potensial untuk menyumbang terjadinya limpasan permukaan.

Limpasan air yang berasal dari wilayah terbangun tersebut perlu dikelola dengan cara meresapkannya ke dalam permukaan tanah. Untuk membuat disain optimal dari resapan air hujan tersebut diperlukan data analisis laju resap air ke dalam tanah oleh karena itu diperlukan penelitian mengenai infiltrasi di kawasan.

Menurut Schwab (1981), Infiltrasi adalah masuknya air melalui permukaan tanah dan yang berbeda dari perkolasi, yang adalah pergerakan air melewati profil tanah. Kira-kira tiga perempat dari total hujan diatas permukaan bumi kembali secara langsung ke atmosfer melalui evaporasi atau transpirasi. Sebagian besar dari kesetimbangan itu kembali ke laut sebagai aliran permukaan atau aliran subpermukaan. Infiltrasi menjadi bagian yang penting dalam siklus hidrologi. Jika cukup air, maka air infiltrasi akan bergerak terus ke bawah yaitu ke dalam profil tanah. Gerakan air ke bawah di dalam profil tanah disebut perkolasi. Istilah perkolasi dalam digunakan, untuk menunjukkan perkolasi air jauh ke bawah daerah perakaran tanaman yang normal.

Jika air hujan meresap kedalam tanah maka air tersebut akan bermanfaat baik bagi tanaman, maupun sebagai sumber air tanah. Jika laju infiltrasi pada suatu area resapan tinggi, maka air hujan yang akan menjadi runoff/limpasan di atas permukaan tanah menjadi sedikit, hal ini juga akan dapat bermanfaat terhadap pengurangan erosi.

Laju infiltrasi adalah banyaknya air persatuan waktu yang masuk melalui permukaan tanah. Laju infiltrasi biasanya dinyatakan dalam $\mathrm{mm} / \mathrm{jam}$ atau $\mathrm{cm} / \mathrm{jam}$. Pada saat tanah masih kering, laju infiltrasi tinggi. Setelah tanah menjadi jenuh, maka laju infiltrasi akan menurun dan menjadi konstan. Kemampuan tanah untuk menyerap air infiltrasi pada suatu saat dinamai kapasitas infiltrasi tanah.

Pergerakan air ke tanah melalui infiltrasi bisa dibatasi oleh hambatan terhadap aliran dari air melalui profil tanah. Walaupun hambatan ini sering terjadi di permukaan tanah, juga bisa terjadi di beberapa tempat di kisaran rendah dari profil. Hal yang paling penting yang mempengaruhi kecepatan infiltrasi berkaitan dengan karakter fisik tanah dan penutupan permukaan tanah, tetapi faktor lain seperti kelembaban tanah, suhu dan intensitas curah hujan juga mempunyai pengaruh.

Ada dua parameter penting berkaitan dengan infiltrasi yaitu laju infiltrasi dan kapasitas infiltrasi. Laju infiltrasi (f) adalah kecepatan masuknya air ke dalam tanah pada waktu tertentu. Laju infiltrasi dinyatakan dalam $\mathrm{mm} / \mathrm{jam}$ atau $\mathrm{cm} /$ jam. Pada saat tanah kering laju infiltrasi tinggi, setelah tanah menjadi jenuh air maka laju infiltrasi akan menurun dan menjadi konstan. Parameter infiltrasi lainnya adalah kapasitas infiltrasi (fp), didefinisikan sebagai kemampuan tanah untuk menyerap air infiltrasi pada suatu waktu tertentu. Infiltrasi dibatasi oleh karakteristik tanah dan ketersediaan air $(\mathrm{R})$ untuk infiltrasi, bila ketersediaan air $R<f p$ maka $f=R ; f<f p$ dan jika $R>f p$ maka $f=f p$; $R>f$.

Sri Harto (1993) mengilustrasikan keterkaitan antara infiltrasi dengan perkolasi dalam suatu sketsa hubungan antara infiltrasi dan perkolasi pada suatu profil tanah pada Gambar 1. Pada kondisi antara laju infiltrasi dan perkolasi yang tidak seimbang. Kondisi semacam ini sama-sama tidak menguntungkan terutama untuk masuknya air sebagai sumber air tanah. Gambar 1.a. profil tanah lapisan atas mempunyai laju infiltrasi kecil tapi lapisan bawah mempunyai laju perkolasi tinggi, sebaliknya pada gambar 1.b. lapisan atas dengan laju infiltrasi tinggi sedangkan laju perkolasi pada lapisan bawah rendah.

Pada Gambar 1.a., meski laju perkolasi tinggi tapi laju infiltrasi yang memberikan masukan air terbatas. Dalam keadaan seimbang kedua kenyataan ini ditentukan oleh laju infiltrasi. Sebaliknya pada Gambar 1.b. laju perkolasi yang rendah menentukan keadaan seluruhnya. Dalam kenyataannya, proses yang terjadi tidak sesederhana itu, karena adanya kemungkinan aliran antara.

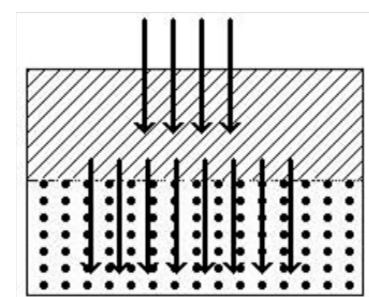

(a)

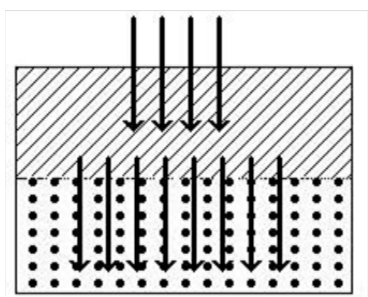

(b)
Gambar 1. Skema infiltrasi dan perkolasi pada dua lapisan tanah (a). Infiltrasi kecil dan perkolasi besar. (b). Infiltrasi besar dan perkolasi kecil (Sri Harto, 1993)

Jika air dalam tanah tidak bergerak vertikal akan tetapi ke arah horisontal, maka proses ini 
dinamai rembesan lateral atau menyamping. Rembesan lateral terjadi disebabkan oleh permeabilitas berbagai lapisan tanah yang tidak seragam. Air yang masuk lapisan tanah atas dengan laju yang agak cepat, mungkin tertahan oleh lapisan yang permeabilitasnya lambat atau kedap air, sehingga air tertahan dan kemudian air mengalir ke arah lateral yang keluar dipermukaan tanah di kaki lereng bawah.

Infiltrasi air ke dalam tanah diawali ketika tanah dalam keadaan tidak jenuh, yang terjadi dibawah pengaruh sedotan matriks dan gaya gravitasi. Jika infiltrasi berlangsung terus maka semakin banyak air infiltrasi yang masuk ke dalam tanah sehingga profil tanah menjadi basah, akibatnya sedotan matriks akan berkurang. Berkurangnya sedotan matrik disebabkan karena semakin jauhnya jarak antara bagian tanah yang kering dan yang basah. Jika proses infiltrasi terus berjalan dan seluruh lapisan tanah menjadi basah maka sedotan matrik menjadi dapat diabaikan, sehingga gerakan air ke bawah di dalam profil tanah hanya disebabkan oleh gaya gravitasi. Inilah menjelaskan mengapa laju infiltrasi air ke dalam tanah semakin berkurang dengan bertambahnya waktu (lamanya) hujan seperti terlihat dalam Gambar 2.

Dalam pengukuran laju infiltrasi di lapangan lebih sering menggunakan metode double ring infiltrometer (Gregory, et al. 2005). Double ring infiltrometer terdiri dari atas dua buah ring yaitu ring dalam dan ring luar. Kedua ring dimasukkan kedalam tanah dan diisi dengan air pada ketinggian tertentu. Laju infiltrasi ditentukan dari jumlah air yang masuk kedalam tanah pada satu satuan waktu tertentu. Penggunaan double ring infiltrometer lebih menguntungkan dari pada penggunaan single ring infiltrometer disebabkan karena ring luar mengurangi kesalahan pengukuran akibat lateral flow air didalam tanah.

Terdapat dua teknik pengukuran double ring flowmeter yaitu constant head test dan falling head test. Pada constant head test, level air dalam ring tetap dijaga. Banyaknya air yang digunakan untuk mempertahankan volume inilah yang diukur sebagai laju infiltrasinya. Berbeda dengan constant head test, falling head test tidak mempertahankan level air pada ring melainkan dibiarkan berkurang. Waktu pengurangan level air pada ring tersebutlah yang diukur. Dalam pengukuran menggunakan kedua teknik ini, level air pada ring luar tetap dipertahankan konstan untuk mencegah kebocoran antar ring. Prosedur pengukuran laju infiltrasi dapat merujuk kepada standard yang ditetapkan pada ASTM standard. Pada ASTM standard diameter ring telah ditentukan yaitu untuk ring dalam berdiameter 30 $\mathrm{cm}$, diameter luar adalah $60 \mathrm{~cm}$.

Tujuan dilakukannya pengukuran infiltrasi adalah untuk mengetahui kapasitas tanah dalam meresapkan air hujan. Mengetahui kapasitas infiltrasi kawasan pada unit lahan kering (bergunung) dan basah (lahan gambut).



Gambar 2. Laju infiltrasi sebagai fungsi waktu pada kondisi tanah basah dan kering (Arsyad, 2006)

\section{METODOLOGI PENGUKURAN INFILTRASI}

Untuk pelaksanaan penelitian ini dilakukan tahap sebagai berikut:

1. Menentukan satuan lahan: Satuan Iahan ditentukan melalui kajian geomorfologi, dimana setuap satuan lahan ini secara geomorfologi terbentuk melalui struktur dan proses yang sama, litologi yang sama dan pola penggunaan lahan yang sama. Wilayah kawasan Teknopark Pelalawan ini secara satuan lahan terbagi menjadi dua satuan lahan yaitu satoan lahan dengan topografi lebih tinggi, bergelombang, kering dan satuan lahan rendah, basah dengan jenis lahan gambut. Kedua satuan lahan tersebut menjadi wilayah sasaran pengukuran infiltrasi.

Melakukan pengukuran di lokasi terpilih: Pengukuran infiltrasi tersebut dilakukan dengan menggunakan ring infiltrasi dobel, Prosedur pengukuran data dilakukan dengan tahap sebagai berikut:

- Tentukan titik lokasi pengukuran, bersihkan dari ilalang atau pengotor.

- Tancapkan Ring dalam kedalaman kira-kira $10 \mathrm{~cm}$, Letakkan balok penahan ring di atas ring kecil dan tancapkan ring kecil (ring dalam) sampai dengan kedalaman $10 \mathrm{~cm}$. 
Pukul balok penakan dengan menggunakan pemukul.

- Tancapkan Ring luar dengan kedalaman kira kira $10 \mathrm{~cm}$, ulangi juga untuk menancapkan ring luar dengan menggunakan cara seperti waktu memasukkan ring kecil. Tancapkan ring luar sampai dengan kedalaman $10 \mathrm{~cm}$, dicirikan dengan air yang tidak merember keluar

- Isikan air pada ring dalam dan pastikan air tidak bocor keluar.

- Isikan air pada ring luas dan pastikan air tidak bocor keluar.

- Catat data penurunan muka air pada ring dalam dengan waktu interval 5 (lima) menit.

- Buat grafik hubungan antara komulatif dari waktu pengukuran (menit) dengan komulatif penurunan muka air ( $\mathrm{cm}$ atau $\mathrm{mm}$ ). Akumulasi infiltrasi adalah total jumlah air yang masuk kedalam tanah pada selang waktu tertentu. Akumulasi infiltrasi dihitung menggunakan persamaan ke (1)

- Dengan menggunakan Software Microsoft Excel lakukan analisis trendline untuk mendapatkan rumus persamaan dan koefisien regresinya dengan menggunakan tool Trend /Regression Type dan sajikan rumus persamaam dan koefisien regresinya kedalam grafik.

- Untuk menghitung besarnya laju infiltrasi maka persamaan laju infiltrasi dideferensialkan, sehingga rumus persamaan menjadi seperti persamaan ke (2). Rumus laju infiltrasi yang sudah didapat dari deferensial dari $\mathrm{dF} / \mathrm{dt}$ digunakan untuk membuat tabel hubungan antara kumulatif waktu (t) dengan I.

- Buat grafik hubungan antara t dengan I, kemudian tarik garis laju infiltrasi pada garis konstan untuk mendapatkan besarnya laju infiltrasi pada percobaan menggunakan ring infiltrometer ( $\mathrm{mm} / \mathrm{menit}$ ) atau laju volume peresapan pada sumur resapan (liter/menit).

- Buat grafik hubungan antara komulatif dari waktu pengukuran (menit) dengan komulatif penurunan muka air ( $\mathrm{cm}$ atau $\mathrm{mm}$ ). Akumulasi infiltrasi dihitung menggunakan persamaan ke (1)
- Dengan menggunakan Software Microsoft Excel lakukan analisis trendline untuk mendapatkan rumus persamaan dan koefisien regresinya dengan menggunakan tool Power Trend / Regression Type dan sajikan rumus persamaan dan koefisien regresinya kedalam grafik.

- Untuk menghitung besarnya laju infiltrasi maka persamaan laju infiltrasi dideferensialkan, sehingga rumus persamaan seperti persamaan ke (2).

- Buat grafik hubungan antara t dengan I, kemudian tarik garis laju infiltrasi pada garis konstan untuk mendapatkan besarnya laju infiltrasi pada percobaan menggunakan ring infiltrometer ( $\mathrm{mm} / \mathrm{menit}$ ) atau laju volume peresapan pada sumur resapan (liter/menit).

2. Analisis Hasil: Perhitungan infiltrasi dilakukan dengan rumus Kostiakov. Rumus untuk mengukur infiltrasi adalah sebagai berikut:

$$
\begin{aligned}
& F_{c}=k t^{n} \\
& I=d F / d t=k n t^{n-1}
\end{aligned}
$$

3. Pelaporan: Penulisan laporan dilakukan setelah analisis terhadap data pengukuran dilaksanakan.

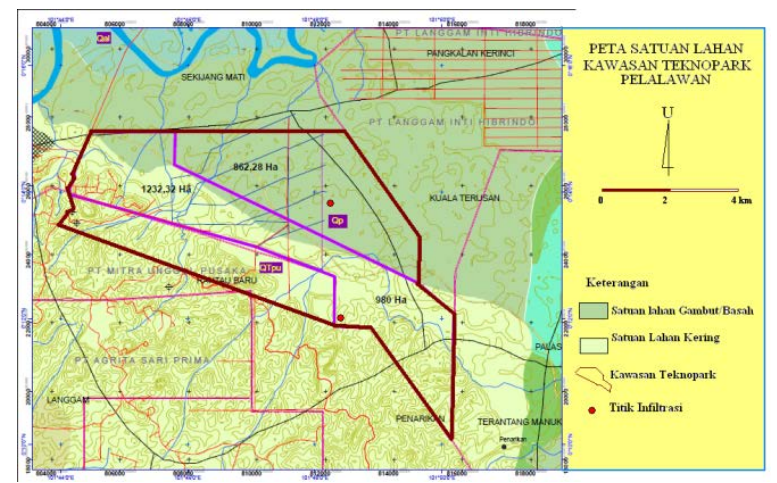

Gambar 3. Peta Satuan Lahan Kawasan Teknopark Pelalawan

\subsection{Peralatan}

1. 2 Buah Ring Infiltrometer

2. Penggaris

3. Tangki air - bahan baku

4. Alat ukur waktu

5. GPS

6. Alat tulis dan Catatan

\section{HASIL ANALISIS}

Pengukuran infiltrasi dilakukan pada satuan lahan gambut dan lahan kering. Pengukuran lahan 
gambut terletak pada koordinat UTM 0810849, 0026413. Sedangkan untuk lahan kering dilakukan pada koordinat UTM 0812265, 0021847.

Lahan gambut di kawasan teknopolitan pelalawan terletak dibagian utara kawasan. Lahan gambut pada kawasan teknopolitan dapat dilihat pada Gambar 3. Lahan gambut kawasan teknopolitan ini pada umumnya berada pada lahan dengan topografi relatif datar.

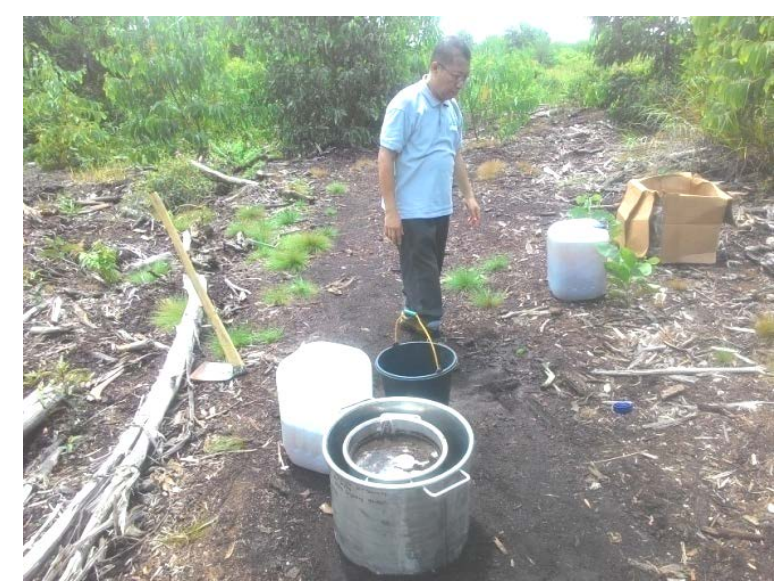

Gambar 3. Kondisi lapangan lahan gambut kawasan teknopolitan Pelalawan

Lahan kering kawasan teknopolitan Pelalawan berada pada bagian selatan. Kondisi lapangan lahan kering pada kawasan teknopolitan Pelalawan dapat dilihat pada Gambar 4. Topografi lahan kering kawasan teknopolitan secara umum dapat dikatakan sedikit bergunung-gunung atau bergelombang.



Gambar 4. Kondisi lapangan lahan kering kawasan teknopolitan Pelalawan

Pengukuran dilahan gambut menunjukkan dalam selang waktu 0 hingga 135 menit, komulatif penurunan muka air adalah sebesar $74 \mathrm{~mm}$. Hasil perhitungan komulatif infiltrasi pada lahan gambut berdasarkan data pengukuran dapat dilihat pada Gambar 5.
Pengukuran dilahan kering dilakukan dalam selang waktu 140 menit. Dari hasil pengukuran diperoleh data penurunan muka air sebesar $407 \mathrm{~mm}$. Hasil perhitungan akumulasi infiltrasi pada lahan kering ditunjukkan lewat grafik pada Gambar 6.

Perhitungan laju infiltrasi pada lahan kering dan lahan gambut masing - masing menggunakan persamaan ke (2). Laju infiltrasi lahan gambut adalah $1,722 \mathrm{t}^{-0,289} \mathrm{~mm} / \mathrm{menit}$ dan laju infiltrasi lahan kering adalah $18,53 \mathrm{t}^{-0,52} \mathrm{~mm} /$ menit. Grafik laju infiltrasi hasil perhitungan pada lahan gambut dapat dilihat pada Gambar 7 dan pada lahan kering dapat dilihat pada Gambar 8.

Dari perhitungan laju infiltrasi lahan gambut dan lahan kering Hasil analisis data pengukuran pada lahan gambut menghasilkan laju infiltrasi konstan sebesar $0,4 \mathrm{~mm} / \mathrm{menit}$ dan pada satuan lahan kering sebesar $1,5 \mathrm{~mm} / \mathrm{menit}$.

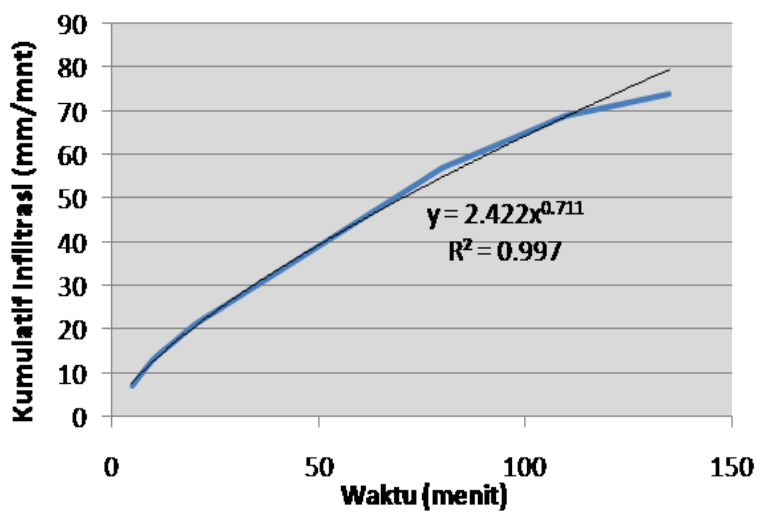

Gambar 5. Grafik Kumulatif Infiltrasi Satuan Lahan Gambut Pelalawan

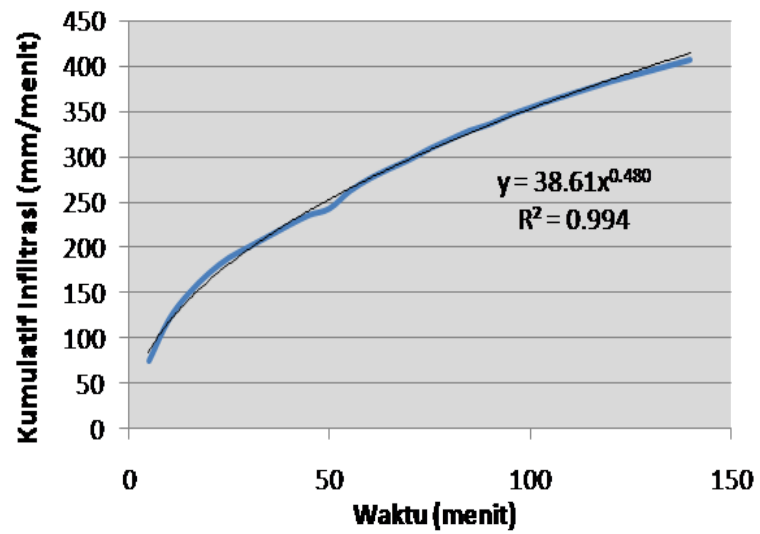

Gambar 6. Grafik Kumulatif Infiltrasi Satuan Lahan Kering Pelalawan

\section{PEMBAHASAN}

Akumulasi infiltrasi antara lahan gambut dan lahan kering sangatlah berbeda. Penurunan muka air dilahan mencapai 5 kali dari penurunan muka air 
dilahan gambut. Perbedaan ini terutama sangat dipengaruhi oleh tekstur, kelembaban tanah, kedalaman muka air tanah, dan banyak sedikitnya perakaran atau aktifitas organik dalam tanah.



Gambar 7. Grafik Laju Infiltrasi Satuan Lahan Gambut Pelalawan

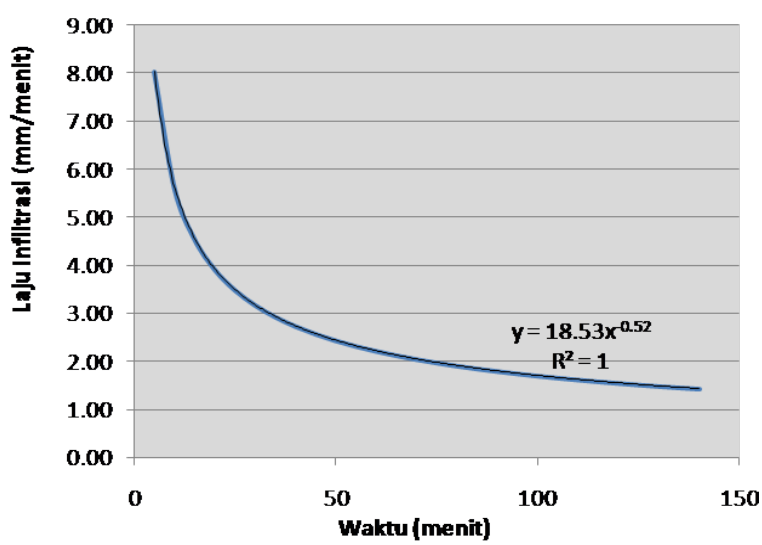

Gambar 8. Grafik Laju Infiltrasi Satuan Lahan Kering Pelalawan

Laju infiltrasi dilahan kering kawasan teknopark Pelalawan lebih tinggi dari lahan gambut. Besar perbedaan laju infiltrasi konstan antara dua lahan tersebut mencapai $1,1 \mathrm{~mm} /$ menit. Sesuai dengan metode Green - Ampt, tingkatan infiltrasi suatu lahan mengindikasikan besarnya suction head dan tingkat permeabilitas tanah. Hal ini berarti bahwa permeabilitas tanah di lahan kering lebih tinggi dibandingkan permeabilitas tanah di lahan gambut kawasan teknopark.

Manfaat mengetahui tingkat permeabilitas adalah dalam pembuatan sumur resapan untuk mengatur tingkat limpasan lahan akibat pembangunan. Dimana nantinya perubahan tata guna lahan pada kawasan akan mempengaruhi tingkat limpasan. Perubahan tingkat limpasan sebelum pembangunan dan setelah pembangunan haruslah bernilai 0 . Maksudnya adalah bahwa pembangunan di kawasan teknopark tidak boleh menambah atau mengurangi limpasan daerah tersebut $(\Delta Q=0)$. Sehingga untuk mengurangi kelebihan limpasan pada kawasan, dibangunlah sumur resapan terutama pada lahan gambut dengan laju infiltrasi yang rendah.

\section{METODOLOGI PENGUKURAN INFILTRASI}

Dalam kegiatan pengukuran infiltrasi pada technopark pelalawan dapat ditarik beberapa kesimpulan yaitu :

- Hasil pengukuran penurunan permukaan air dengan menggunakan double ring infiltrometer pada lahan gambut dikawasan technopark pelalawan dalam selang waktu 135 menit adalah $74 \mathrm{~mm}$

- Hasil pengukuran penurunan permukaan air dengan menggunakan double ring infiltrometer pada lahan kering dikawasan technopark pelalawan dalam selang waktu 140 menit adalah $407 \mathrm{~mm}$

- Laju infiltrasi lahan gambut di kawasan technopark pelalawan adalah 1,722 $\mathrm{t}^{-0,289}$ $\mathrm{mm} / \mathrm{menit}$ dan laju infiltrasi lahan kering di kawasan technopark pelalawan adalah $18,53 \mathrm{t}$ $0,52 \mathrm{~mm} /$ menit

- Laju infiltrasi konstan pada lahan gambut di kawasan technopark adalah 0,4 $\mathrm{mm} /$ menit dan pada lahan kering di kawasan technopark lahan kering sebesar $1,5 \mathrm{~mm} /$ menit

\section{DAFTAR PUSTAKA}

- Schwab. 1981 (Schwab GO, Frevert RK, Edminster TW and Barnes KK (1981). Soil and water conservation engineering : (3rd Edition). John Wiley and Sons, New York, NY. 525. ISBN 0-47103078-3.)

- Arsyad. 2006 (Arsyad, Sitanala., 2006. Soil and Water Conservation. Bogor Agriculture Institute. IPB Press.)

- Sri Harto. 1993 (Br. Sri Harto., 1993, Analisis Hidrologi, Gramedia Pustaka Utama, Jakarta)

- ASTM D 3385-03. Standard Test Method for Infiltration Rate of Soils in Field Using Double-Ring Infiltrometer. Explanation, ASTM International, 2003.

- Gregory, J. H, Michael D. Dukes, Grady L. Miller, and Pierce $H$. Jones. "Analysis of Double-Ring Infiltration Techniques and Development of a Simple Automatic Water Delivery System." Applied Turfgrass Science, 2005.

- Lal, Rattan, and Manoj K. Shukla. Principles of Soil Physics. New York: Marcel Dekker, Inc., 2004. 